UWM, Olsztyn

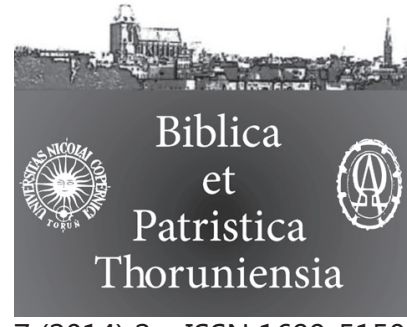

7 (2014) 2 ISSN 1689-5150

DOI: http://dx.doi.org/10.12775/BPTh.2014.011

\title{
Tak zwany List Jeremiasza (Ba 6) Pochodzenie, forma i przesłanie
}

\section{The so-called Letter of Jeremiah (Bar 6) Origin, form and message}

Słowa klucze: List Jeremiasza; Księga Barucha; idolatria; polemika z politeizmem; religia babilońska; satyra na kult bożków.

Keywords: Epistle of Jeremiah; Letter of Jeremiah; Book of Baruch; idolatry; polemics against polytheistic religion; Babylonian religion; satire against idolatry.

Streszczenie. List Jeremiasza jest prawdopodobnie grecką kompozycją napisaną w III wieku przed Chrystusem w jakiejś części Mezopotamii będącej pod wpływem helleńskiej władzy i kultury. Nawet jeśli jego treść idzie za biblijną krytyką idolatrii, to formułuje on te same idee w szczególny sposób. Przyjmuje on grecki krytycyzm w stosunku do religii, znany nam u Herodota z Ezopowych bajek i niektórych filozofów. To dzieło jest satyryczną mową, co wyjaśnia pewne jego cechy, jak brak obiektywności i powtarzalność stylu. Wydaje się lepiej zaplanowany niż to zazwyczaj się przyjmuje (wprowadzenie i dwie strofy z dwoma argumentami każda). On pomagał przekonać zhellenizownych Żydów, aby nie dali się zwabić pozornym splendorem pogańskiego kultu. Idole są tylko materialnymi przedmiotami, które nie są w stanie działać, a ich kapłani są skorumpowani.

Abstract. The Letter of Jeremiah is probably a Greek composition written in the third century B.C. in the part of Mesopotamia influenced by the Hellenistic rule and culture. Even if its contents follows the biblical criticism against idolatry, it formulates the same ideas in a particular way. It has also absorbed some Greek criticisms against religion, known to us from Herodotus, Aesopic fables and some philosophers. This work is a satiric speech, what explains some its features, as the lack of objectivity and repetitious style. It seems better planned that it is usually assumed (introduction and ten strophes with two arguments each). It aims at convincing the Hellenized Jews that that should not be allured by the ostensible splendour of the pagan cult. The idols are only material objects, they have no capacity to act and their priests are corrupted. 
Księga Barucha jest niejednolita, gdyż wprowadzenie (Ba 1,1-14), część Lpokutną (Ba 1,15-3, 8), partię o mądrości (Ba 3,9-4, 4) i dwa poematy prorockie o Jerozolimie $(4,5-5,9)$ należy przypisać różnym autorom. Jest to powszechnie przyjęte wśród badaczy ${ }^{1}$. Na pewnym etapie teksty te zostały jednak połączone w jeden utwór.

Natomiast partię końcową, zwaną Listem Jeremiasza (Ba 6), rękopisy grec-

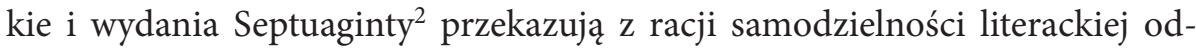
rębnie, przy czym po Księdze Jeremiasza występują zwykle kolejno Ba 1-5, Lamentacje i List Jeremiasza. Były one traktowane najwyraźniej jako osobne dopowiedzenia do głównej księgi. Tylko sporadycznie List następował zaraz po Ba 1-5. Dopiero w tradycji łacińskiej od św. Hieronima począwszy traktowano stale List Jeremiasza jako dodatek do Księgi Barucha. Od całości tej księgi odbija on jednak jaskrawo tematyką i stylem. Powinien więc być omawiany osobno.

Poświęcony jest on specjalnie kultowi bożków. Przybiera on formę listu przypisanego prorokowi Jeremiaszowi, choć $\mathrm{w}$ istocie stanowi raczej mowę napominającą. Na wstępie wzywa do uczczenia jedynego Boga. Następnie w formie satyrycznej przedstawia bezsilność bożków, podatność ich wizerunków na zniszczenie oraz chciwość i zakłamanie kapłanów pogańskich.

\section{Geneza utworu}

Badając pochodzenie Ba 6, należy najpierw rozpatrzeć kwestię języka oryginalnego. Badacze nowsi zakładali zwykle, że List Jeremiasza powstał w oryginale po hebrajsku, chociaż w XIX w. przeważał pogląd o oryginale greckim (Fritsche i Schürer). Zmiana ta powstała pod wpływem tłumaczenia trudnych miejsc tekstu jako skutku niezrozumienia oryginału hebrajskiego. ${ }^{3}$

Takich miejsc jest jednak zaledwie kilka i można je wyjaśniać inaczej (np. Ba 6,11.30.54.72). Albo brzmienie greckie wcale nie wymaga poprawek, albo też autor pisząc po grecku, myślał po hebrajsku. Żydowski autor całości, nawet

1 Główne komentarze: C.A. Moore, Additions; O.H. Steck, R.G. Kratz i in., Das Buch Baruch; I. Assan-Dhôte, Moatti-Fine, La Bible d'Alexandrie. Baruch. Por. też mniejsze: A. Alonso Schökel, J.-L. Sicre Diaz, Baruc; A.H.J. Gunneweg, Das Buch Baruch. Pol. L. Stachowiak, Lamentacje. Ksiega Barucha

2 Najnowsze i najlepsze wydanie krytyczne: Ieremias, Baruch, ed. J. Ziegler. Z niego biorę numerację wersetów, choć czasem niezbyt naturalną i miejscami odmienną niż u Rahlfsa i w gros tłumaczeń.

3 Najpierw C.J. Ball, The Epistle of Jeremy, w: R.H. Charles (red.), The Apocrypha. Przytaczają to i rozwijają nowsze komentarze, choć część badaczy widzi i cechy oryginalnie greckie tekstu. 
pisząc po grecku, mógł bowiem okazjonalnie korzystać z tekstów semickich i używać semityzmów. I tak w w. 11 komentatorzy uważają tekst „nie bronią się przed śniedzią i próchnieniem” za niejasny, gdyż nie dostrzegają, że występujące tu gr. brōma, oprócz typowego znaczenia „pokarm”, które jest nieodpowiednie, oznacza też „zjedzenie, spróchnienie, zeżarcie, zepsucie” (zęba, drewna?), co pasuje do kontekstu, gdzie mowa o bogach drewnianych.

Próbują jednak w oparciu o domniemany oryginał hebrajski poprawić „próchnienie” na „robaki”, „mole” (tak już przekład starołaciński; por. Ml 3,11; Hi 13,28), albo też na „odór” (gr. bromos, występuje w Hi 6,7; Jl 2,20 - LXX). Być może znaczenia te łączy odniesienie do padliny (która się kojarzy i z pokarmem, i z zepsuciem, i z odorem). W recenzji Lucjana pojawia się forma od pokrewnego brōsis, co również oznacza „coś do jedzenia”, w tym mięso, a skądinąd „rozkład, zepsucie” (zęba); por. Mt 6,19.

W w. 30 „kapłani zasiadają”. Gr. difreuousin oznacza w zasadzie „powożąa", co rodzi trudność, ale etymologicznie słowo to odnosi się do zasiadania, a tylko wtórnie do czynności woźnicy (gdyż ten siedzi na ławce). Mogłoby to ewentualnie znaczyć w przenośni również „kierują, ciągną za sznurki”. Szukano tu jednak błędnego tłumaczenia hebr. rdzenia nhg, który znaczy „powozić" oraz „jęczeć, zawodzić"; ten drugi sens pasowałby do kontekstu, ale to nie jest konieczne. Możliwa jest też hipoteza, że chodzi o eufemizm oznaczający zaspokajanie na siedząco potrzeb naturalnych (por. Sdz 3,24 LXX: pros difrous kathestai). Ustęp zanieczyszcza miejsce kultu.

W w. 54 bożki są ,jak wrony pomiędzy niebem a ziemią”. Możliwa byłaby poprawka wrony na "chmury”, na podstawie domniemanego tekstu hebrajskiego, spółgłoskowo k'bjm, ,jak chmury”, odczytany jako k'rbjm, „jak kruki”. Nie jest to jednak niezbędne: wrony bezsilnie kraczą, a chmury ulegają wiatrowi. Oba porównania są możliwe.

W w. 72 słowo „marmurze” (marmarou) budzi sprzeciw komentatorów, którzy poprawiają na „bisiorze”, „Inie”, „szkarłacie” (Wulgata). Wynika to z domniemanego oryginału hebrajskiego ze słowem šêš, które może oznaczać i marmur, i drogą tkaninę. Skoro jednak chodzi o posągi bóstw, tekst grecki wskazuje, zapewne świadomie, na nadgryziony zębem czasu kamień rzeźb i nie należy tego brzmienia zmieniać, choćby po hebrajsku było niegdyś inaczej.

Całość nie pod względem językowym kolorytu semickiego i zapewne dlatego żaden badacz nie podjął retranslacji Listu Jeremiasza na hebrajski, inaczej niż przypadku partii poprzednich (choć i tak w przypadku ustępów mądrościowych z Barucha istnienie oryginału semickiego pozostaje niepewne). Pomijam tu oczywiście nowożytne przekłady ksiąg deuterokanonicznych i apokryfów na hebrajski, które z założenia objęły także teksty od początku greckie. 
List Jeremiasza napisany jest dobrą greką, choć nie dorównuje ona językowi literatów i zawodowych retorów. Mieści się jednak w standardzie językowym epoki hellenistycznej i jest wyraźnie lepsza niż generalnie język przekładów z Septuaginty; jest staranna, a czasami nawet wyszukana ${ }^{4}$. Pozostaje dość daleka od stylu semickiego i w szczególności biblijnego, jaki cechuje przekłady z Septuaginty. Pod tym względem różni się zasadniczo od Ba 1-5.

Można też wskazać cechy językowe swoiste dla greki i rzadkie w tłumaczeniach $\mathrm{z}$ hebrajskiego, które w sumie dowodzą, że oryginał całości był grec$\mathrm{ki}^{5}$. Parataksa jest mało używana. Przyimki nie bywają stosowane na sposób semicki. Występują przymiotniki odsłowne z końcówką -teos (Ba 6,39. 44. 51. 56. 63), w Septuagincie bardzo rzadkie (tylko w greckiej w oryginale 2 Księdze Machabejskiej i w Prz 26,23). Występują określenia wstawiane między rodzajnik a słowo określane. Pojawiają się też hapaxlegomena względem tłumaczeń z Septuaginty, słowa skądinąd pasujące do greki hellenistycznej. Na płaszczyźnie rodzaju literackiego tak forma samodzielnego listu, jak forma samodzielnej mowy (w tym przypadku satyrycznej tyrady; zob. niżej), też sugeruje raczej wpływ grecki niż biblijny.

Jeśli utwór ten powstał po grecku w środowisku żydowskim, musiało to być w III w. przed Chr. lub później. Zauważmy jednak, że problemy wiążące się z czasami machabejskimi w II w. zupełnie są w nim nieobecne. Punktem odniesienia jest deportacja do Babilonii i autorytet Jeremiasza, a nie kryzys machabejski. Nie ma żadnych sugestii co do przymuszania do kultu bożków. Nie występuje sprawa przepisów pokarmowych.

Można też uwzględnić okoliczność, że powstała pod koniec II w. przed Chr. 2 Księga Machabejska czyni, jak się wydaje, aluzję do Listu Jeremiasza (2 Mch $2,2)$. Mniejsze znaczenie ma wzmianka o pobycie w Babilonii przez siedem pokoleń przed powrotem (Ba 6,2), gdyż trudno ustalić, czy dotyczy to jakichś konkretnych dat. Jeśli chodziłoby o pokolenia w znaczeniu okresów czterdziestoletnich, List mógłby być datowany na 280 lat po pierwszej deportacji (597 przed Chr.), czyli na 317 przed Chr. - ale czy to też nie byłaby data umowna? W każdym razie List istniał już w I w. przed Chr., skoro w Qumran znaleziono jego mały fragment jego odpisu $\mathrm{z}$ tej epoki (7Q2) ${ }^{6}$.

$\mathrm{Z}$ tej racji powstanie Listu Jeremiasza w III w. przed Chr. lub na początku II w. przed Chr. wydaje się najbardziej prawdopodobne. Gdyby powstał w oryginale po hebrajsku, mógłby być nieco wcześniejszy, ale nie późniejszy. Może

4 Zob. W. Naumann, Untersuchungen. Są oczywiście w LXX i utwory napisane lepiej, jak 2 i 3 Mch.

5 B.G. Wright, The Epistle of Jeremiah.

6 M. Baillet, Lettre de Jérémie. 
być więc wcześniejszy niż Ba 1-5 i niezależny od trzonu Księgi Barucha, co dobrze tłumaczy odrębne miejsce Listu Jeremiasza w rękopisach Septuaginty.

Co z kolei można powiedzieć o jego środowisku? Początek wskazuje na Babilonię, do której uprowadzono Izraelitów (prolog i w. 1-3), potem mowa jeszcze o Chaldejczykach (Ba 6,40). Zagrożeniem wydaje się fascynacja kultem pogańskim ze wspaniałymi wizerunkami bóstw, który z tego powodu utwór wyśmiewa. Celem utworu było głównie ostrzeżenie Żydów przed pokusą uczestnictwa w kulcie pogańskim w Babilonii.

Ta lokalizacja mogłaby być umowna i symboliczna, ale także pewne szczegóły w tekście mają na względzie kult w formach mezopotamskich ${ }^{7}$ : imię Bel, wygląd posągów, atrybuty boskie jak sztylet i topór, odrębna i wpływowa kasta kapłańska, prostytucja sakralna, dostarczanie bóstwom pokarmu, wzmianki o wojnach, pożarach i rabunkach, jakie grożą świątyniom (w czasie wojen między następcami Aleksandra Wielkiego). O wspaniałości wykonania posągów bóstw i ich zdobieniach mówi nieco podobnie akkadycki tekst klinowy z opisem rytuału noworocznego (Akitu), sprawowanego na początku miesiąca Nisan. Pochodzi on zapewne z Babilonu za rządów Seleucydów i opisuje mniejsze, ale wykonane $\mathrm{z}$ najcenniejszych materiałów figurki ${ }^{8}$.

Autor ma więc na myśli sytuację w Mezopotamii względnie w zhellenizowanej wschodniej Syrii, ale już w czasach hellenistycznych, pod władzą dynastii Seleucydów, która miejscowe kulty popierała. Nie oznacza to jednak, że tam mieszkał i pisał, gdyż po pierwsze upraszcza obraz religii babilońskiej, utożsamiając wizerunki z bogami, a po drugie pomija kluczowy dla niej czynnik, astrologię i wróżbiarstwo. List mógł być także dziełem Żyda mieszkającego w kraju Izraela lub Syrii i atakować pośrednio kult tamtejszy, syryjski bądź grecki. Faktem pozostaje jednak, że z kultem typu greckiego zbieżności są tylko ogólne (wielobóstwo, świątynie i posągi); specyfiki sąsiedniego Egiptu nie widać natomiast wcale.

Autorstwo Jeremiasza jest więc całkowicie pseudonimowe. Nie można nawet powiedzieć, żeby utwór nawiązywał wyraźniej do spuścizny Jeremiasza, choć mogły go inspirować motywy z Jr 10; 29; Jr 40. Zakłada sytuacje tam opisaną i stanowi jej swoistą relekturę, choć mało czerpie z Jeremiasza w warstwie słownej. Wykorzystanie imienia Jeremiasza tłumaczy się dość popularną wtedy metodą pseudonimii, znaną i z Biblii, i z apokryfów, i z literatury greckiej (apokryficzne listy filozofów). Nowe kompozycje przypisywano autorytetom $z$ dal-

7 W. Naumann, Untersuchungen 3-31.

8 Zbiór TUAT, t. 2, s. 212-223, zwł. 214-215; por. D.H. Steck, Kratz, Das Buch Baruch, 92. 
szej przeszłości. Kontynuowano w ten sposób i uzupełniano naukę mistrzów, dodając zarazem powagi i autorytetu swoim dziełom.

\section{2. Źródła}

Z jakich źródeł korzystał List Jeremiasza? Dość powszechnie wiąże się go z biblijnymi polemikami przeciw kultowi bożków. Wspólne punkty z nimi oczywiście występują, ale nie mają charakteru bezpośrednich zapożyczeń. Treściowo jest to bowiem polemika przeciw kultowi bożków, ale prawie nie spotkamy w niej nawiązań do sformułowań biblijnych.

Podobnych polemik z kultem bożków znajdziemy w hebrajskiej Biblii kilka9: Pwt 4,28; Iz 44,9-20; 45,20; 46,6-7; Jr 10,2-15; 51,15-19; Ha 2,18-19; Ps 115,3-8; 135,5-7. 15-18. Ich autorzy naigrawają się z wizerunków bożków jako martwych przedmiotów wykonanych przez rzemieślników, niby wspaniałych, ale całkowicie bezsilnych. Ten satyryczny chwyt powtarza się w Liście Jeremiasza. Powtarzają się wzmianki o srebrze, złocie i zdobieniach (Iz 40,19; Jr 10,4. 9; Ez 16,18), o niezdolności do ruchu i stania samodzielnie (Iz 40,20; 41,7; Jr 10,4), braku tchnienia (Jr 10,5) oraz słuchu i wzroku (Ps 115,5).

Zarzuty zawarte w Liście są jednak liczniejsze i szersze niż w tych tekstach; dodano wiele swoistych porównań; dodano nowe motywy, jak brud na bożkach, nieczystość ich kultu, nieuczciwość kapłanów. Brakuje za to typowych dla innych polemik biblijnych zestawień z Bogiem prawdziwym. Inaczej niż całość Księgi Barucha, nasyconej terminologią biblijną i aluzjami biblijnymi, List Jeremiasza, przytaczając liczne przykłady bezsilności bożków, stosuje raczej własne sposoby mówienia. Nie występują typowe terminy na oznaczenie idoli: samo eidolon tylko w w. 72, który wygląda na dodatek; brakuje glypton, choneuton, agalma, eikon, bdelygma, mataia. Z Septuaginty zaczerpnięto jedynie ogólny język kultowy, używany w Pięcioksięgu.

Wprawdzie początek Listu streszcza tradycję o uprowadzeniu Żydów do Babilonii, ale potem tematyka biblijna i teologiczna znika $z$ wywodu. Jedyne wyraźniejsze powiązanie z tekstami powyższymi, to podobieństwo $\mathrm{Ba} 6,66$ 71 do Jr 10,2-5, z bardzo charakterystycznym motywem stracha na wróble i grządki ogórków (melonów?). Ale i tu nie ma cytatu, lecz ślad znajomości tego samego motywu. Ustęp końcowy listu, gdzie te słowa się znajdują, mógłby być zresztą żydowskim dodatkiem typu redakcyjnego.

W swej istocie satyra na bożki w Liście Jeremiasza powiela schemat biblijny. Utożsamiając bóstwo z jego wizerunkiem, kieruje ataki na wizerunek, którego

9 Por. Jelonek, Satyra. 
słabości nietrudno dowieść. Wobec braku bezpośrednich nawiązań do tradycji biblijnej w argumentacji szczegółowej trzeba jednak zapytać o inne inspiracje. Grecki język tej polemiki i kontekst państw hellenistycznych sugeruje zapożyczenie z greckiej krytyki religii, które w tym przypadku postulowałem, uwzględniając też Dn 14 i Mdr $14^{10}$. Poniżej skorzystam więc do swojego artykułu na ten temat, $\mathrm{z}$ pewnymi skrótami.

Satyra z Ba 6 mogła być oparta na tego typu wzorach, uzupełnionych potem z monoteistycznego punktu widzenia. Ustęp Ba 6,1-6 zawierałby wprowadzenie napisane przez autora żydowskiego, który chciał wykorzystać gotową satyrę przeciwko bożkom (w. 3 może pochodzić ze źródła). Następnie następuje dłuższa sekcja centralna, w której napotykamy satyrę na bożki względnie bogów (Ba 6,7-57), oraz uwagi o kapłanach (Ba 6,9. 17. 27-32). Sekcja końcowa na temat fałszywych bogów (Ba 6,58-72), która zestawia bożki z królami, siłami natury, zwierzętami, strachami na wróble oraz ludźmi sprawiedliwymi, brzmi w tym kontekście jak końcowa konkluzja autora żydowskiego, gdyż odnosi się do jedynego Boga i uwzględnia motywy z Jr 10.

Natomiast obszerna sekcja centralna nie wymienia jedynego Boga ani też specyficznych zwyczajów żydowskich (z możliwymi mniejszymi wyjątkami w ww. 15,27 i 50, które jednak albo nie muszą być tłumaczone jako wyraz wpływu żydowskiego, albo wynikły z interwencji redakcyjnych) ${ }^{11}$. Mamy więc tu pięćdziesiąt wersetów biblijnych z krytyką bożków, ale bez wzmianki o jedynym Bogu. Na tle całego Pisma Świętego jest to zaskakujący wyjątek.

Te ostre krytyki same w sobie brzmią ateistycznie. Reprezentują pogląd na świat, w którym głównymi siłami są przyroda, ludzie i zwierzęta. Sekcja ta wygląda na luźne zestawienie głównych argumentów przeciwko wierze w bogów: bierność ich posągów, nieuczciwość kapłanów oraz słabość wobec wrogów i zagrożeń. Dla tych motywów mamy szereg paralel greckich, wyjąwszy kwestię zepsucia kapłanów, która kojarzy się raczej z tłem bliskowschodnim. Herodot (Dzieje 2,172) przytacza anegdotę o faraonie Amazisie. Miał on sporządzić posąg boga ze złotej miednicy używanej do mycia nóg i jako nocnik. Następnie ogłosił to i wyjaśnił, że jest to obraz jego wyniesienia: był byle kim, a teraz jest faraonem. Herodot opowiada też o Amazisie (Dzieje 2,174nn), że odmówił czci wyroczniom, które go niesłusznie uwolniły od zarzutu kradzieży.

10 M. Wojciechowski, Starożytna krytyka.

11 W. 16: „ich bogowie” sugeruje żydowski punkt widzenia, ale niekoniecznie; w. 27 może odzwierciedlać żydowskie reguły czystości (ale też nie musi); w w. 50 chodzi o działanie jakiegoś boga, a nie Boga jedynego. 
Satyry na wizerunki i na samych bogów występują w zbiorze bajek Ezopowych ${ }^{12}$. Większość tych bajek istniała już w IV w. przed Chr., nawet jeśli część znana jest formach późniejszych (po łacinie lub w przeróbce wierszowanej Babriosa). Mimo braku bezpośrednich związków z Ba 6, satyry te reprezentują zbliżone podejście. Są ważne jako dość wczesne świadectwo literatury popularnej, odbicie greckiej tradycji ustnej, która mogła być znana w świecie biblijnym.

Wieśniakowi zginęła motyka, więc podejrzanych o kradzież wziął do miasta, by zaprzysięgli wobec bogów, że są niewinni (bajka nr 295/402, Babrios 2). Tymczasem usłyszał, że świątynię okradziono, a za odzyskanie skarbów oferowana jest wielka nagroda. Uznał to za dowód bezsilności bóstwa.

Kamieniarz rozważa, czy sprzedać popiersie jako pomnik nagrobny, czy też jako figurę boga Hermesa. Hermes mówi mu we śnie: „Teraz będzie moja sprawa się ważyła: uczynisz mnie martwym, czy też jednak bogiem?" (307/405, Babrios 30). Dosadniej brzmi anegdota o hermie, którą pies chciał uczcić. Hermes na to: „Obyś tylko tego nie oblizał, czym mnie namaszczono, i na mnie nie sikał" (308/406, Babrios 48). Istnieją dalsze bajki o wizerunkach Hermesa $88 / 108,89 / 110,285 / 61$ (por. 182/266). Wszystkie przejawiają brak szacunku dla nich. Inne bajki pokazują postępki bogów wątpliwe moralnie (89/110, 309/112, 103/111, 28/55, 278/44). Bogowie nie karzą za złamanie ślubu (34/46; Ba 6, 34) i nie pomagają czcicielom $(30 / 53,291 / 72$ = Babrios 20, 231/356; Ba 6, 36). Znany starożytny ateista, Diagoras, wspominany już przez współczesnego mu Arystofanesa, miał porąbać na opał posąg Heraklesa.

Pewni autorzy klasyczni mieli być przeciwni kultowi wizerunków. Odpowiednie dane pochodzą głównie z drugiej ręki, od autorów chrześcijańskich, mogą być więc w części apokryficzne. Klemens Aleksandryjski cytuje słowa Sofoklesa $\mathrm{z}$ listą materiałów do wytwarzania wizerunków, podobną do list biblijnych (Zachęta Greków 74,1). Tenże Klemens znalazł u Heraklita paralelę do biblijnych stwierdzeń o niemocie bożków (Zachęta Greków 50,4): „A oni modlą się do tych posągów, jak gdyby ktoś chciał prowadzić rozmowę z domami”.

Wiele źródeł wspomina Zenona jako krytyka kultu wizerunków i budowania świątyń. W tym przypadku zależność od tradycji biblijnej nie jest wykluczona, gdyż Zenon był pochodzenia fenickiego. Niemniej jednak takie poglądy mogły inspirować grecką krytykę religii, a poprzez nią późniejsze teksty biblijne. Wyraźny cytat znajdziemy u Klemensa (Stromateis 5, 76, 1). Pogląd ten przytacza Cyceron (De natura deorum 1, 27, 77 i 1, 36, 101) oraz Plutarch

12 Cytuję na pierwszym miejscu numery z wydania Perry’ego, które jest najpełniejsze. Na drugim miejscu numery z mojego tłumaczenia polskiego: Ezop i inni, które cytuję. Mój artykuł o stosunku bajek Ezopowych do religii, z którego też korzystam: M. Wojciechowski, Religia. 
(Moralia 1034b). Własna opinia Plutarcha była podobna (Moralia 382b). Krytykiem wizerunków byłby jeszcze Seneka (według św. Augustyna, De civitate Dei 6,10 i Laktancjusza, Divinae institutiones 2,2). Późniejsze odzwierciedlenie tego krytycyzmu znajdziemy u Lukiana.

\section{Cechy literackie}

Teraz skupię się na budowie i gatunku tego utworu. Na początku znajduje się jednozdaniowy prolog, który się często pomija w numeracji wersetów (podobnie jak prolog Mądrości Syracha). Prolog ten mógł jednak należeć do tekstu pierwotnego, jeśli jego autor od początku zamierzył przypisanie utworu na sposób pseudoepigraficzny prorokowi Jeremiaszowi.

Sam utwór zawiera 72 wersety (numeracja $\mathrm{z}$ wydanie Zieglera). Od strony formalnej dzieli się na jedenaście akapitów, z których pierwszy służy za wprowadzenie $^{13}$. Następne, mimo że napisane prozą, można nazwać zwrotkami, gdyż są porównywalnej długości i zostały podobnie rozplanowane. Każda zawiera satyryczne przedstawienie bożków pogańskich i kończy się wnioskiem, że posągi nie są bogami, czyli swoistym refrenem. Całość zamyka jednozdaniowe podsumowanie (w. 72). Podobną budowę, z podziałem na strofy i refrenami znajdziemy w Ps 42-43.

Pierwszy ustęp, wprowadzenie, zawiera ostrzeżenie pod adresem Żydów prowadzonych do Babilonii, że nie powinni czcić tamtejszych bogów (akapit I, w. 1-6). Jest to jedyny fragment, który nawiązuje jawnie do tradycji biblijnej. Potem nie ma ani wzmianek o Bogu jedynym, ani wyraźniejszych aluzji biblijnych, mimo sporadycznego występowania motywów znanych także z ksiąg prorockich oraz ramowego podobieństwa treści do żydowskich krytyk idolatrii.

To sugeruje, co odnotowałem powyżej, że wykorzystano tutaj satyrę na bożków ze świata zewnętrznego. W takim razie pierwszy akapit stanowiłby żydowskie wprowadzenie do takiej satyry. Akapit końcowy (XI, w. 69-71) może stanowić żydowskie dopowiedzenie, próbę kontynuacji. Zawiera bowiem specyficzne metafory znane z Księgi Jeremiasza. Ponadto już akapit IX jest nieco dłuższy i zawiera coś w rodzaju konkluzji (w. 63). Z drugiej strony można by też łączyć akapity X i XI w jeden, który jako końcowy miałby budowę mniej regularną niż poprzednie.

Na końcu każdego akapitu jak refren powtarza się wniosek, że posągi bożków nie są bogami. Trzeba to stwierdzić i dlatego nie należy się ich bać. Trzon

13 C.A. Moore, Daniel, Esther and Jeremiah, i inni. 
każdego akapitu zawiera argumenty na rzecz tej tezy, przeważnie dwa. Za każdym razem są one inaczej sformułowane, choć pozostają spokrewnione i po części się powtarzają; brakuje wyraźnej systematyzacji, autor dość bezładnie krąży wokół tematu. Niemniej jednak stara się, by argumentacja była bogata i kompletna.

Akapit II: bożki są wytworem ludzi i nie są w stanie walczyć (w. 7-14). Akapit III: są bezużyteczne, martwe i niszczeją (w. 15-22). Akapit IV: są kosztowne, ale nieruchome, z ofiar korzystają kapłani (w. 23-28). Akapit V: ich kult jest niegodny, nie pomogą potrzebującym (w. 29-39). Akapit VI: nie mają zmysłów, a kultowi towarzyszy nierząd (w. 40-44). Akapit VII: ukształtowali je rzemieślnicy, w obliczu najazdu trzeba je ukrywać (w. 45-51). Akapit VIII: nie rządzą i niszczeją w pożarze (w. 52-56a). Akapit IX: ulegają złodziejom i stoją niżej niż żywioły (w. 56b-64). Akapit X: ustępują władcom, ciałom niebieskim i zwierzętom (w. 65-68). Akapit XI: są bezsilne jak krzaki i trupy (w. 69-72).

W konstrukcji tekstu można się dopatrywać elementów chiazmu ${ }^{14}$. Np. wzmianka o purpurze powtarza się w w. 11 i 71 (za Jr 10,9?), w pierwszej i ostatniej zwrotce. Wzmianki o królach i zwierzętach pojawiają się w drugiej i w przedostatniej itd. Na tej zasadzie pierwszych pięć zwrotek znajduje pewien, choć luźny odpowiednik w następnych pięciu. Powtórzenia, które odbiera się jako nużące, były w pewien sposób zaplanowane.

Budowa tekstu jest dość regularna, choć nie do końca konsekwentna. Całość ma cechy mowy, publicznej deklamacji z silnym elementem retorycznym. Język jest bogaty, barwny, odwołuje się do emocji. Służy to przekonaniu odbiorcy, słuchacza czy czytelnika. Poza akapitem wstępnym, nawiązującym treścią do biblijnego zakazu idolatrii, sposób potraktowania tematu jest wyraźnie satyryczny. Stosuje się umyślną przesadę, a argumentacja jest jednostronna i skupia się na patologiach towarzyszących kultowi pogańskiemu. Stylistycznie operuje negacjami i antytezami. Mowa ma charakter prześmiewczy, można by ją sobie wyobrazić raczej jako tyradę w kabarecie niż jako wykład czy kazanie.

W kontekście mowy budowa stroficzna nie jest typowa. Tłumaczono ją pomysłowo chęcią naśladowania hymnów, skierowanych do Boga lub bożków. List Jeremiasza byłby „hymnem na odwrót”, parodią hymnu ${ }^{15}$. Mogło to być inspirowane przez okoliczność, że potępienia idolatrii są w Biblii podporządkowane pochwałom prawdziwego Boga. Bardziej banalnie można uznać to za skutek powtarzania podobnych do siebie argumentów (por. budowę stroficzną Ps 119).

14 G.J. Brooke, The Structure.

15 W.M.W. Roth, For Life; por. Beentjes, Satirical Polemics. 
Konwencja listu ma tu charakter drugorzędny i umowny. Bez wzmianki z prologu nie wiedzielibyśmy nawet, że ma to być list. Mowę czy wyrocznię można było wysłać jako list, przeznaczając ją do odczytania (przykładem Jr 29, listy Pawłowe, Ap).

Terminy „list” i „odpis” (epistole, antigrafon) w ramach Septuaginty okazują się zdecydowanie najczęstsze w księgach deuterokanonicznych, co wskazuje na wpływ grecki. Pod względem formalnym List Jeremiasza nie naśladuje jednak listów hellenistycznych, lecz zbliża się raczej do listów zawartych w pismach apokryficznych, a za model ma zapewne list z Jr 29, tym bardziej, że zakłada sytuację w tym rozdziale opisaną. Niemniej jednak i samodzielna mowa, i samodzielny list to gatunki typowe raczej dla świata greckiego niż dla Starego Testamentu.

Satyra jako forma literacka była w starożytności dobrze znana. Mogła brać za cel wadliwą religijność (Horacy, Satyry 1, 8, 1-7 o Priapie). Często miała intencję moralizatorską, to znaczy piętnowała wady, błędy i złe czyny. Satyra ośmiesza i neguje, czemu nie musi towarzyszyć przedstawienie pozytywnej alternatywy. Nie pretenduje do obiektywizmu. Często kieruje się przeciw temu, co społecznie jest uznane i wpływowe. Cechy te odnajdujemy w Liście Jeremiasza. Atakuje on i ośmiesza religię typu pogańskiego, dominującą w świecie starożytnym, tylko krótko zaznaczając, co uważa za jej alternatywę.

Jak to już zaznaczyłem powyżej, język grecki mowy odbiega od popisowej greki zawodowych retorów i literatów, ale mieści się w standardzie języka epoki hellenistycznej i jest lepszy niż generalnie język Septuaginty. Jest dość daleki od stylu semickiego i w szczególności biblijnego. Pod tym względem różni się zasadniczo od Ba 1-5, gdzie mamy do czynienia najpierw z przekładem $z$ hebrajskiego, a potem, od $\mathrm{Ba} 3,9$, z tekstem zapewne greckim w oryginale, ale na tyle zabarwionym stylem semickim, że można bronić tezy, że stanowi on przekład. Mimo że również List Jeremiasza uważano za przekład $z$ oryginału hebrajskiego, znacznie więcej świadczy za oryginałem greckim.

\section{Zamysł i doktryna}

Celem Listu Jeremiasza wydaje się odsunięcie od Żydów niebezpieczeństwa apostazji, czyli rezygnacji ze swojej tożsamości i fascynacji zewnętrznym bogactwem i wspaniałością świata pogańskiego. Absurdalność kultu bożków i towarzysząca mu niemoralność powinny wykluczyć wszelkie pozytywne zainteresowanie dla religijności pogańskiego otoczenia. Stoi ona w oczywisty sposób niżej od religijności czcicieli Jahwe. Jest też obrazą dla zdrowego rozsądku. Pogaństwo opiera się na głupocie i strachu przed bożkami. W takim razie trwa- 
nie przy wierze żydowskiej jest naturalnym rozwiązaniem. Teologia stojąca za Biblią i kultem Izraela, jest tu założona, ale nie stanowi treści przesłania.

Cel utworu jest bowiem typu praktycznego. Odpowiada potrzebom swojego miejsca i czasu i nie przedstawia innych religii w sposób ogólniejszy czy bardziej pogłębiony. Ujęcie tematu jest dość popularne, podobnie jak w innych biblijnych satyrach na bałwochwalstwo. ${ }^{16}$ Powierzchowne spojrzenie na kult wizerunków ma zapewne na względzie percepcję ludzi prostych. Autor zajmuje się zewnętrznymi formami kultu pogańskiego, nie przedstawiając ani nie atakując istoty religii pogańskiej, czci dla sił natury (chociaż w Starym Testamencie motyw ten występuje, zob. Mdr 13,1-9).

Choć argumentacja przeciw bożkom przedstawiona została mało systematycznie, można za nią dostrzec wyraźną konstrukcję myślową. W punkcie wyjścia autor tendencyjnie zakłada tożsamość wizerunków z bogami, co mogło odpowiadać uczuciom części pogan, ale na pewno nie zgadzało się z pojęciami religijnymi ludzi wykształconych, czy to w świecie starożytnego Wschodu, czy w greckim. To sztuczne założenie bardzo ułatwia krytykę bożków.

Przyjęcie takiego założenia wiąże się z satyrycznym, rozmyślnie nieobiektywnym charakterem utworu. Wynika również stąd, że skoro posągi pojmowano jako wizerunki bóstw, byłyby do nich pod pewnym względem podobne i równie ułomne. Pojmowanie wizerunków jako symboli jest w tej satyrze pominięte, może zresztą poganie sami nie zawsze umieli tę ideę wyartykułować. Przypomina się tu autyzm, wada sposobu postrzegania świata, którą charakteryzuje między innymi trudność odróżnienia oryginału od wyobrażenia. Skądinąd dla Biblii wizerunek nie może przedstawiać Boga. Natomiast obrazem Boga jest człowiek, czyli żywa osoba, a nie przedmiot $(\operatorname{Rdz} 1,26)$.

$\mathrm{Z}$ założenia, że posąg to bóg pogan, płyną argumenty szczegółowe. Po pierwsze, bezsilność bożków wynika stąd, że choć wyglądają wspaniale, są przedmiotami z rozmaitych materiałów. Dlatego niczego nie odczuwają ani nie postrzegają, nie mogą też podjąć żadnego działania. Nie mogą nikomu pomóc. Nie mogą się obronić ani przeprowadzić swojej woli. Nie mają władzy typu politycznego ( $w$ domyśle zestawia się ich ze znanymi czytelnikom władcami hellenistycznymi). Posągi wymagają opieki kapłanów, czyszczenia itp.

Następnie, niższości bożków dowodzą rozmaite porównania. Zestawia się ich z ludźmi, wtedy okazuje się, że jako wytwórcy bożków stoją oni wyżej od nich - a przecież są tylko ludźmi. Królowie, najeźdźcy i zwykli zbójcy są dla bożków zagrożeniem, gdyż nie mogą się im przeciwstawić. Zestawia się je z rozmaitymi przedmiotami, które są przynajmniej użyteczne. Zestawia się je z siłami natury, które pod względem blasku i potęgi bardzo przewyższają bożki,

16 W.M.W. Roth, For Life; T. Jelonek, Satyra. 
choć same są posłuszne Bogu i prawom rządzącym światem (jak już zaznaczyłem, autor nie bierze pod uwagę tego, że w religijności typu pogańskiego bogowie są uosobieniem sił natury). Porównuje się wreszcie bożki ze zwierzętami, które przynajmniej mogą się poruszać i uciekać.

Ostatnia grupa zarzutów dotyczy tego, co się dzieje wokół bożków. Kapłani żyją z kultu i jeszcze okradają swoich bogów, co oznacza, że się z nimi w ogóle nie liczą. Do kultu dopuszczane są kobiety, także w okresie nieczystości rytualnej. Kultowi towarzyszy prostytucja. Zwierzęta mogą zanieczyszczać bożki, pokrywa je też zwykły brud.

Kult bożków jawi się więc jako śmieszny, głupi i nieczysty, skąd płynie wniosek, że uczciwy człowiek, który odrzuca taką religię, ma rację (Ba 6,72). Trzeba wyzbyć się bojaźliwej fascynacji wobec bożków, przestać uznawać je za sacrum. Wszelkie argumenty świadczą bowiem przeciw ich boskości, nie sposób jej uznać. Odpowiedzią na kult pogański powinno być nie samo odrzucenie bałwochwalstwa, lecz przede wszystkim wyznanie wiary w Boga jedynego, prawdziwego władcę świata, i oddanie mu hołdu (Ba 6,5). Może on bowiem dokonać tego wszystkiego, do czego bożki nie są zdolne.

Satyryczna polemika $\mathrm{z}$ wielobóstwem może się wydawać dość odległa od problemów dzisiejszych. Jednakże, choć kult babiloński należy już do przeszłości, nadal istnieją religie z elementami absurdalnymi bądź niemoralnymi, których satyryczne potraktowanie nie byłoby niczym zdrożnym. Warto też zachować zdecydowany krytycyzm wobec tego, co czci i czcić każe dzisiejsza imponująca cywilizacja.

\section{Bibliografia}

Alonso Schökel A., Sicre Diaz J.L., Baruc, w: Nueva Biblia Espagnola. Comentario, Profetas, t. 2, Madrid 1980, s. 1309-1340.

Artom E.S, Lorigine, la data e gli scopi dell'Epistola di Geremia, Annuario degli Studi Hebraici 1(1935), s. 49-74.

Asensio F., Carta de Jeremias, w: La Sagrada Escritura. Texto y comentario Antiguo Testamento, t. 5, Madrid 1970, s. 703-712.

Assan-Dhôte I., Moatti-Fine J., La Bible d'Alexandrie. Baruch, Lamentations, Lettre de Jérémie, Paris 2005.

Baillet M., Lettre de Jérémie, w: Les 'Petites Grottes' de Qumran (Discoveries in the Judean Desert of Jordan 3), Oxford 1962, s. 143.

Beentjes P. C., Satirical Polemics Against Idols and Idolatry in the Letter of Jeremiah (Baruch ch. 6), w: P.W. van der Horst (red.), Aspects of Religious Contact and Conflict in the Ancient World, Utrechtse Theologische Reeks 31, Utrecht 1995, s. 121-134. 
Brooke G.J., The Structure of the Poem against Idolatry in the "Epistle of Jeremiah" (1 Baruch 6), w: Poussières de christianisme et de judaïsme antique (Publications de l'Institut roman des sciences bibliques 5), Fs. J.-D. Kaestli, E. Junod, red. A. Frey, R. Gounelle, Lausanne 2007, s. 107-128.

Charles R.H. (red.), The Apocrypha and Pseudepigrapha of the Old Testament, t. 1, Oxford 1913, s. 569-611 (I Baruch: O.C. Whitehouse; The Epistle of Jeremy: C.J. Ball).

Ezop i inni. Wielka ksiegga bajek greckich, opr. M. Wojciechowski, Kraków 2006.

Grecko-polski Stary Testament. Księgi greckie. Przekład interlinearny z kodami gramatycznymi i indeksem form podstawowych, opr. M. Wojciechowski, Warszawa 2008.

Gruen W., A sabedoria de um excluído: atualidade da Epístola de Jeremias, Estudos Bíblicos 48(1996), s. 34-42.

Gunneweg A.H.J., Das Buch Baruch. Der Brief Jeremias, w: Historische und legendarische Erzählungen (JSHRZ III/2), Gütersloh 1975, s. 165-192.

Hurowitz V., An End to Flying Cats - Epistle of Jeremiah 22 Reconsidered, Journal for the Study of Pseudepigrapha 1999, z. 20, s. 93-95.

Ieremias, Baruch, Threni, Epistula Ieremiae (Septuaginta. Vetus Testamentum Graecum 15), ed. J. Ziegler, Göttingen 1957.

Jelonek T., Satyra $w$ walce $z$ batwochwalstwem, w: Oto idę, Fs. J.B. Szlaga, red. W. Chrostowski. Warszawa 2005, s. 200-217.

Kellermann D., Apokryphes Obst. Bemerkungen zur Epistula Jeremiae (Baruch, Kap. 6), insbesondere zu Vers 42, Zeitschrift der deutschen morgenländischen Gesellschaft 129(1979), s. 23-42.

Kratz R.G., Die Rezeption von Jeremia 10 und 29 im pseudepigraphen Brief de Jeremia, JSJ 26(1995), s. 2-31.

Lee G.M., Apocryphal Cats: Baruch 6, 21, VT 21(1971), s. 111-112.

Moore C.A., Daniel, Esther and Jeremiah: the Additions (AB 44), New York 1977, s. 253-358.

Naumann W., Untersuchungen über den apokryphen Jeremiasbrief (BZAW 25), Berlin 1913, s. 1-53.

Perry B.E., Aesopica, t. 1: Greek and Latin Texts, Urbana (Illinois) 1952.

Roth W.M.W., For Life, he Appeals to Death (Wis 13:18): A Study of Old Testament Idol Parodies, CBQ 37(1975), s. 21-47.

Septuaginta, ed. A. Rahlfs, t. 1-2, Stuttgart 1935.

Stachowiak L., Lamentacje. Ksiega Barucha. Wstęp - przekład z oryginału - komentarz (PŚST 10/2), Poznań 1968.

Steck O.H., Kratz R.G. i in., Das Buch Baruch, Der Brief des Jeremia. Zusätze zu Esther und Daniel (Das Alte Testament Deutsch. Apokryphen 5), Göttingen 1998.

Steck O.H., Das apokryphe Baruchbuch. Studien zur Rezeption und Konzentration „kanonischer" Überlieferung (FRLANT 160), Göttingen 1993.

Wojciechowski M., Cat or Marten? Ailouros in Baruch 6:21[22] and in Aesop's Fables, Biblische Notizen, w druku.

Wojciechowski M., Religia i jej krytyka w greckich bajkach Ezopowych, Nomos 2006 nr 55/56, s. 23-47. 
Wojciechowski M., Starożytna krytyka religii w Dn 14 (Bel i Wąż), Ba 6 (List Jeremiasza) i Mdr 14, ZN SBP 5(2008)5, s. 277-292 = Wojciechowski M., Ancient Criticism of Religion in Dan 14 (Bel and Dragon), Bar 6 (Epistle of Jeremiah), and Wisdom 14, w: Deuterocanonical Additions of the Old Testament Books. Selected Studies (Deuterocanonical and Cognate Literature Studies 5), red. G.G. Xeravits, J. Zsengellér, Berlin / New York 2010, s. 60-76.

Wolff C., Jeremia im Frühjudentum und Urchristentum (TU 118), Berlin 1976.

Wright B.G., The Epistle of Jeremiah: Translation or composition?, w: Deuterocanonical Additions to the Old Testament Books (Deuterocanonical and Cognate Literature Studies 5), red. G.G. Xeravits, J. Zsengellér, Berlin 2010, s. 126-142. 